\title{
LXXIII. Geological observations, on unstratified Mountains, and on the use and abuse of geological theories
}

\section{Mr. John Farey}

To cite this article: Mr. John Farey (1811) LXXIII. Geological observations, on unstratified Mountains, and on the use and abuse of geological theories, Philosophical Magazine Series 1, 37:158, 440-443, DOI: $10.1080 / 14786441108563315$

To link to this article: http://dx.doi.org/10.1080/14786441108563315

曲 Published online: 18 May 2009.

Submit your article to this journal $\pi$

Џll Article views: 3

Q View related articles $\sqsubset$ 


\section{Geological Observations on unstratified Mountains.}

let fall from that centre on the lines of direction in which the force is applied.

Let $\mathrm{AB}$ (fig. 4.) be the lever, and let the two equal forces $B M, B m$, act upon it at the point $B$, in the direction of the lines $\mathrm{BM}, \mathrm{B} m$. Draw $\mathrm{BN}, \mathrm{B} n$, respectively equal to $B M, B m$, and forming the same angles with the line $P B \omega$ perpendicular to $\mathrm{AB}$. To $\mathrm{BM}, \mathrm{B} m, \mathrm{BN}, \mathrm{B} n$, produced, draw the perpendiculars AY, Ay, AX, A $x$. Now, the side $A X=A Y$, and $A x=A y$, on account of the equality of tha triangles, $A B X, A B Y$; and if $M l, M \lambda$, be drawn perpendicular to $\mathrm{B} \omega$, the triangles $\mathrm{ABY}, \mathrm{BM} l$, will be similar, and also the triangles $\mathrm{AB} y, \mathrm{~B} m \lambda$; hence we obtain

$\mathrm{AB}: \mathrm{AY}=\mathrm{BM}: \mathrm{B} l$, and

$\mathrm{AB}: \mathrm{A} y=\mathrm{BM}: \mathrm{B} \lambda$

Therefore, ex aquo, $\mathrm{AY}: \mathrm{A} y=\mathrm{B} l: \mathrm{B} \lambda$.

Complete the parallelograms $\mathrm{BM} o \mathrm{~N}, \mathrm{~B} m \omega n$, and $\mathrm{B} l$, $B \lambda$ will be respectively one-half of the diagonals $B o, B w$.

Now let two equal forces $B M, B N$, act in these directions upon the lever at $B$, their joint force will be represented by the diagonal $\mathrm{BO}$, and consequenlly one of the forces $B M$ will be represented by $\mathrm{B} l=\frac{\mathrm{I}}{2} \mathrm{~B} O$. In the same manner, if the two equal forces $B m, B n$, act upon the lever at $B$, their joint force will be represented by $B \omega$, and one of them, $\mathrm{B} m$, will be represented by $\mathrm{B} \lambda=\frac{1}{2} \mathrm{~B} \omega$. Consequently the power of the two forces $B M, B m$, to turn the lever round its centre of motion, is represented by $\mathrm{B} l, \mathrm{~B} \lambda$, respectively; that is, the force BM is to the force $\mathrm{B} m$ as $\mathrm{B} l$ is to $B \lambda$; that is, as $A Y$ is to $A y$, the perpendiculars let fall upon the lines of their direction.

LXXIII. Geological Observations, on unstratified Montains, and on the IJse and Aluse of Geological Theories: By Mr. John Farey, Senior.

\section{Ta Mr. Tilloch.}

SrR, $I_{T}$ gives me considerable pleasure, after so long a lapse, to observe Dr. William Richardson rerurning to the subject of geology, in which he has already achieved so much, and from whom we expect still greater things, and to see him among the contributors to the Philosophical and Geological Magazine; not that I mean to insinuate that the doctor's labours elsewhere on Finrin Grass, have been unimportant or not highly useful; but I confess that I have not

been 
been able to refrain from joining, in the regret expressed of late by most of my friends, that it was not transferred, in great part at least, to those who could render less important aids to science.

It must be learnt with satisfaction by all well-wisners to geology, that a statistical survey is in hand, in which the stratification of Antrim will be fully treated of by this able observer, and 1 wish that in a future communication Dr. R. would inform us of the state of forwardness, and when this work may be expected to appear.

It is now near 20 years since Mr. William Smith discovered several large Hummocks resembling that of Knocklaid mentioned by Dr. Richardson, but on smaller scales probably, in the vicinity of Bath; and when I was receiving instructions from him ten years ago, he explained the several strata to me, on his coloured map, on a large scale, of the environs of Bath; and it will be learnt with surprise by Dr. Richardson and many others, that he then held (and does so yet for aught I know to the contrary) that these bold and solitary Hills were originally formed as they now stand, -a position which I could never give into, but combated from the first, with so much freedorn, that we have since discussed this subject less than any others among his important discoveries, except that of Faults, on which latter subject, I learnt very little from Mr. S., nothing indeed, which could lead to a theory of them, or their important operations on the strata.

Although. I fully agree with the conclusions of Dr. Richardson (p. 360), as to a great part of the Mountains and Hills being left behind, or carved out as it were, from more extended strata than we now see, as all those in Derbyshire will I think appear to be, from the facts I have stated in my Report on Derbyshire, lately published, vol. i. and in a paper some time ago presented to the Royal Society, yet, I am no less certain, that many other Mountains, and perhaps most of those having as $\mathrm{Mr}$. Davy expresses it (page 392 of your last number) a crystalline texture and a stratification approaching to the perpendicular, and many others with somewhat different characters, may without impropriety be said to be formed, since their masses are the effects of nodular concretions, in which different sub- ances were applied laterally and partially to or by the side of, or lapped round each other, in a wanner perfectly distinct from the regular and parallel stratification of which Dr. Richardson speaks, and which have been the object of Mr. Smith's researches. 


\section{Geological Obsenatisis on unstratifua Liontaing.}

Immediately on my return from viewing of Chernwood Forest, in Leicestershire, in August 180 opinion, that this primituve tract, as some call it, not only formed one of these exceptions to regular stratification, but that it was a huge noditlar concretion in the red carth or gypseous marl, underldying the las clay; and 1 have been more and more convinced by reading, correspondence and conversation ever since to the present time, that most, or perhaps every one of the tracts deemed primitive, or supposed hitherto, to be projecting points of the solid usucleus of the earth, in the British isles, are referable to similar concretions or anomalisus masses in the upper, or in some of the inferior strata of these marls, of which $I$ suspect that there are three at least, of very great thickness, interlaid with coal-measures and limestnne rocks, also of great thickness. Whether the larger of the nodular concretions on the surface of the carth, such for instance as the lofty Alps, which I see strong reasons for referring to nodula masses in strata, that are underlait by the chalk of London and Paris, were ever entirely covered by strata, that have been stript off them, or only partially on their skirts, that is, whether the world was ever as much larger, as to include the summits of these vest mountain chains or not, as Dr. Richardson hints, it may be very difficult to determine; but it will be easy I think to show, in the smaller nodular tracts, like that of Chernwond Forest and others in England, that the surrounding and covcring strata have been denudated or swept away, and that in this sense they have been left, according to Dr. Richardson's concluding remark. I much wish that Dr. R. could be induced to extend his observations beyond the regularly stratified district to which, if I mistake not, they have been confined, to the nearest mountain or primitive tracts, and favour the world with his observations on the connection and distinctions between them; and for that purpose I have thrown out these hints for his consideration, and comparison with the phanomena: assuring him, that I am not liss sensible of the importance of facts than himself, and hope to live to prove the same to the world : but as the phitosophic end of all experimental or observed facts, is to obiain a theory or general knowledge of the principles which connect all those fscts, my opinion is, that they ought to go on together; and that they may heneficially do so, I am satisfied fully, from my own experience in this particular pursuit, and in attending to the progress of chemical knowledge and others, of which 1 nay staie mysell to be rather a spectator, than as taking 
any part in them. I may add, that theories seem perfectly harmless, when advanced by humble individuals like myself, and free from the evil justly complained of, that of their being retailed in books, lectures, \&c. for ages together, because advanced by great men, without due inquiry into their validity, or any comparisons being made of the gross inconsistencies which may exist between such theories, and the most obvious of geological phænomena, and while many others of the most important kind, were either wholly unknown, or wilfully overlooked, by the framers of such thenries (see your xxxiiid volume, page 313 ). Thus much I have been desirous of saving, on a subject, on which I daily witness greater mistakes than in any other, great numbers of persons having gone over from one extreme, that of implicitly receiving theories from great anthority, to the not less mischievous one, of clamorously crying down all theories or attempts at generalization. I am determined however, not to be influenced by these circumstances, but always while viewing or contemplating the phanomena of nature, to give free scope to comparisons of them with existing theory, or to the imagination in search of others, which may seem to explain them better: and when afterwards, the facts and the reasonings or theory are faithfully stated together, it is impossible, I maintain, that any harm to science can come from them, while much good may result from the discussion which a new theory may excite.

$$
\begin{aligned}
& \text { I am, sir, } \\
& \text { Westminster, June 4, 1811. Your obedient servant, } \\
& \text { Johs FAREY. }
\end{aligned}
$$

P. S.-The comparison which I have lately made with the List of Derbyshire Hills at page 162, of your present volume, and the proul of the Map of them engraverl for my Report, have detected a few errata in the forrer, which I beg here to state for correction, viz. Page 165 , line 4 from bottom, before Gorsey insert W.-Page 168, line 19, before Wollaton insert E.-P 169 , line 26 , before Clond insert W, and line 34, before Mole insert W.-P. 170, line 10, for (Green) read (Blue), and line 12, before Ertori insert $W .-P .171$, line 4 , for $S$ read $N$, and line 7 , before Petycroft insert S.-And p. 174, line 8, before Lose insert E. 